\title{
TRUE SPIDERS INHABITING DATE PALM VARIETIES WITH SPECIAL REFERENCE TO THE BIOLOGICAL ASPECTS OF THANATUS ALBINI REARED ON RED PALM WEEVIL, RHYNCHOPHORUS FERRUGINEUS IN EGYPT
}

\author{
M. H. El-Erksousy ${ }^{(1)}$, H. M. Heikal ${ }^{(2)}$ and Amal I. Abozid ${ }^{(1)}$ \\ (1) Plant Protection Research Institute, Dokki, Giza, Egypt \\ (2) Economic Entomology and Agricultural Zoology Dept., Fac. of Agric., Menoufia Univ., \\ Shebin El-Kom, Egypt.
}

Received: Mar. 29, 2018

Accepted: Apr. 21,2018

\begin{abstract}
This article was conducted to survey true spiders inhabiting three varieties of date palm in Egypt, as well as the biological aspects of Thanatus albini, Audouin, (Araneae: Philodromidae) on larvae of red palm weevil, Rhynchophorus ferrugineus ,Olivier, (Coleoptera : Curculionidae) to know the possibility of control the larvae of red palm weevil by the spider T. albini as a biological control method. Date palm fruits of Samani variety was chosen from El-Beheira Governorate represented soft date variety and Siwi variety used as semi-dried variety from Fayoum Governorate while Apremy variety was the dried fruits variety tested from Aswan Governorate. Also, Menoufia, Cairo, Gharbia, Sharkia, Dimetta, Giza, Fayoum, Beni-Sweief, Menia and Aswan Governorates were chosen for study the abundance of spiders in stores. The date palm fruits were collected and identified during the study period from October 2016 till September 2017. The obtained results which conducted on different date palm varieties indicated that the soft and semi dried varieties harbored many of spiders and these spiders obviously decreased in the dried varieties. The obtained data indicated also that the most abundant families were Philodromidae and Salticidae on leaves and Miturgidae, Hersilidae and Lycosidae associated with fruits in the field and on stored date fruits. The biological aspects of the $T$. albini reared on the larvae of the red palm weevil, $R$. ferrugineus at $25 \pm 2{ }^{\circ} \mathrm{C}$ and $60 \pm 5 \% \mathrm{RH}$ indicated that the life cycle of the tested spider was $169.87 \pm 5.29$ and $148.73 \pm 3.37$ days for female and male, respectively. The food consumption of both female and male was $491.83 \pm 46.81$ and $310.35 \pm 47.76$ larvae of the red palm at the same pervious conditions, respectively.
\end{abstract}

Key words: true spiders, date palm, red weevil, biological control.

\section{INTRODUCTION}

True spiders are fascinating animals that appeared on the earth during the carboniferous geological era, about 300 million years ago. Spiders live in different habitats, in arid regions and wet lands, in low lands and mountains, in cold tundra and in hot equatorial regions, moreover spiders are predators at all. In Egypt spiders are one of the more diverse arthropod taxa, ranking as seventh grade in global diversity, which makes them a fascinating group to study (Agnew, et al.,
1985 , Coddington, 1986, Barrin and Litsinger 1995). The Egyptian spider fauna still incompletely known due to scarcity of studies on this group especially in Upper Egypt.

In Egypt spiders are found to be predators on insects and mites, which cause damages for many agricultural crops. The predacious habits of spiders are beneficial in the control of different pests. In Egypt, Hussein, 1999, ElErksousy, 2000 studied the seasonal abundance and activity patterns of spider 
fauna in some vegetable fields in Menoufia, Nile Delta. Spiders belongs to order : Araneae are among one of the most rich groups of terrestrial animals, included more than 45,000 spider species belonging to 114 families described so far and many thousands still awaiting discovery and description (World Spider Catalog, 2015). In Egypt, there are 40 families belonging to $\mathbf{1 9 3}$ genera and $\mathbf{3 8 5}$ species (El-Hennawy, 2002, 2006, 2010). Furthermore, Ibrahim, et al., 2012 surveyed true spiders in wheat, cotton and maize fields, in Egypt.

The date palm fruits contain high ratio of sugars more than $75 \%$ of their weight, so it can be regard as the most important fruits containing heat energy. Many important industries have been initiated on them and are considered the main income of many inhabitants. Date palm fruits produced in Egypt are considered the best date fruit varieties, which can be exported to foreign markets provided that the product qualities are most satisfactory, being free of pest infestation and residues of pesticides. The date palm infested in any of its stages by many of pests (insects and mites) and diseases which make this crop is not desirable and not quality and quantity satisfies. To avoid the hazard use of different chemical pesticides, the recent researches allover the world oriented toward using new approaches for saving the date palm fruits from any harmful sources by using biological control methods including true spiders.

Nowadays, more than 38432 true spider species belonging to $\mathbf{3 5 4 2}$ genera in $\mathbf{1 1 0}$ families were identified, Plantnich (2004). In Egypt, El-Hennawy (2002) listed 385 different spider species in Egyptian fauna belonging to $\mathbf{4 0}$ families. Survey of different spiders associated with date palm in the field and store in Egypt is very rare, Sallam and Yassin (2005) and Sallam et al., (2007).
As for the biology of spiders, Foelix (2011) stated a book on the biology of spiders. In addition, Mohamed and Salam (2003) studied the biology of the true spider, Thomisus spinifer Cambridge (Thomisidae: Araneae), El-Erksousy (2003) studied the biology of the spider, Theridion egyptium Fawzy \& El-Erksousy when reared on Spodoptera littoralis larvae. In addition, El-Erksousy, et al., 2006 determined the Biological aspects of the spider, Steatoda triangulosa, Walkckenare reared on larvae of Spodoptera littoralis ,Boisd. Furthermore, El-Erksousy, et al., 2002 examined the use of the spider, Theridion egyptium sp.n. as biological control agent against cotton aphid, Aphis gossypii Glover, recently, Obuid-Allah et al. (2015) conducted a study on the ecology of spiders at Qena governorate, Egypt, furthermore, Ahmad and Heikal (2016) studied the biological characteristics of the spider, Theridion spinitarse 0 . Pickard-Cambridge, 1876 (Araneae: Theridiidae) in Egypt.

The red palm weevil, Rhynchophorus ferrugineus (Olivier) (Coleoptera: Curculionidae) is the most serious pest to palm where its distribution was registered around the world in about 39 countries and differs also inside the same country. Females of the red palm weevil emerged from its cocoon after completed it sexual organs looking for male and mates. Females lay its eggs on the crevices, roots, offshoots, inside old emerged holes, and caves made by previous infestation. Female last about 23 months and placed from 150-250 eggs singly. Female makes a small grubs by its snout in the tissue and laid its eggs covered with cement material. The resulting larvae of chewing grubs on the fiber ducts (larva doses not eat cellulose but feed on the sap) the sap come up and fermentation happen due to contamination with micro organisms and may come outside the tree by more larval 
activity due to continuous feeding cavities full of eating fibers and sap come outside the tree with special smell and brownish color. In the severally infested trees the stem of palm shown empty and fill with mixture of all stages and boring products. Mostly over lapping generation happen inside one tree. If infestation happens in the head of the tree, toppling occurred. When extensive infestation happen, tree stated to be dray then the adult emergence occur and weevils started to attack new trees (El-Sebay, 2000).

So, this article was conducted to study the survey and the abundance of different spiders inhabiting three varieties of date palm in Egypt, as well as the biological aspects of Thanatus albini on larvae of red palm weevil, Rhynchophorus ferrugineus in Egypt as a safe method to control the larvae of the red palm weevil biologically by the spider T. albini (Audouin).

\section{MATERIALS AND METHODS}

1- Regions and date palm fruit varieties:

Date palm fruits of Samani variety was collected from El-Beheira Governorate represented soft date variety and Siwi variety was used as semi-dried variety from Fayoum Governorate, while Apremy variety was the dried fruits variety which was collected from Aswan Governorate.

\section{2- Survey study:}

The date palm fruits were collected during the study period from October 2016 till September 2017 in different Egyptian habitats in field and store for survey and identification of the collected spiders. El-Beheira Governorate was represented the soft variety (Rashid region) (Samani variety), Fayoum Governorate for semi-dry variety (Siwi variety) and Aswan Governorate for dried variety (Apremy variety). Also, Menoufia,
Cairo, Gharbia, Sharkia, Dimetta, Giza, Fayoum, Beni-Sweief, Menia and Aswan Governorates were chosen for study the abundance of spiders in date palm stores.

The different spiders were collected by handing sorting method using small sieves. The collected samples were conducted monthly during the surveying period. The surveyed spiders were kept in glass vials containing ethyl alcohol $\mathbf{7 0}$ $\%$ and droplets of glycerin.

\section{3- Identification of collected spiders:}

The identification of the collected adult females of spiders were identified depending on the epigynal plate, but in case of males, the palp anatomy is an important factor for identification based on the systems of Petrunkevitch (1939), Kaston (1978) and El-Hennawy (1990).

\section{4- The biological aspects of the spider, Thanatus albini:}

The biological aspects of the spider, Thanatus albini was studied at Plant Protection Research Institute Station, Qaluobia governorate on the larvae of the red palm weevil, $R$. ferrugineus. Eggs of $R$. ferrugineus were collected and maintained at $25 \pm 2{ }^{\circ} \mathrm{C}$ and $60 \pm 5 \%$ RH until hatching, then the newly hatching larvae reared on semi artificial diets contains 1 $\mathrm{kg}$ of sweat potatoes , $250 \mathrm{~g}$ carrot, $20 \mathrm{~g}$ glucose, $4 \mathrm{~g}$ agar, $250 \mathrm{~g}$ cereals, vitamin B (1mg) and vitamin D (0.2 $\mathrm{mg})$, these components dissolved in half liter water (El-Sebay, et al., 2003) in special cages, leaves changed gradually when needed to obtain the larvae of red palm weevil, which used as a prey for $T$. albini. The spiderlings and adult stages of $T$. albini were collected at Qaluobia governorate from date palm trunks where can be getting a lot numbers of spider stages were collected, then transferred to the laboratory to identify. Adult males and 
females were isolated together in a glass tube $20 \mathrm{~cm}$ long and $0.5 \mathrm{~cm}$ in diameter, then closed with a cotton piece. After matting, the female were observed daily until laying their egg sac and hatching of the eggs to obtain the immature stages of this predator. Each spiderling was isolated separately in test tube with prey individuals and gave some individuals and noticed till reaching to adult stages. Number of consumed larvae were estimated during each stage of $T$. albini, as well as the duration of each stage.

\section{RESULTS AND DISCUSSION}

\section{1-Survey of true spiders in field and stores:}

The obtained data in Table (1) indicated that there were five spider species associated with both leaves and fruits of date palm as follows: Philodromus sp (Philodromidae), which was found with high numbers on Samani variety leaves and absent from the rest of other varieties. Also, Theyene imperialis belonging to family Salticidae was collected from the leaves of all tested varieties and from the fruits of Apremy variety, while Chericanthium sp. (Miturgidae) was collected on leaves and fruits of Samani variety only. As for, family Hersilidae, the identification of the collected specimens was not complete because the available individuals were immature stages (spiderlings) with rare numbers on Samani and Apremy fruits, but the family Lycosidae was represented in this study by Hogna ferox as adult stages. The results also showed that the collected families of Philodromidae, Salticidae and Lycosidae were recorded with high numbers on leaves of Samani variety only and this may be due to the kind of the associated pests which may be play an important role on the kind of the collected spider. The obtained results were similar to that obtained by Thang, et al., (1990) and Sallam and Yassin (2005). 2-Survey of different spiders on date palm fruits in stores:

This study was conducted to investigate the different spiders associated with the palm fruits in stores.

The obtained data in Table (2) indicated that there were five spider species, two species only were identified to species level as Hogna ferox (Lycosidae), Thomisus spinifer (Thomisidae), two species only were identified to genus level in this study, Erigone sp. (Linyphiidae) and Uloborus sp. (Uloboridae), and all the spiders were collected with rare number or moderate, while the individuals of the family Hersilidae in this study were immature stages (spiderlings), so identification of them was impossible.

Table (1): Occurrence of spiders collected from date palm trees in the field and stores

\begin{tabular}{|l|l|c|c|c|c|c|c|c|}
\hline \multirow{2}{*}{ Family } & \multirow{2}{*}{ Species } & \multirow{2}{*}{ Stage } & \multicolumn{5}{c|}{ Variety } \\
\cline { 4 - 9 } & & & \multicolumn{2}{c|}{ Apremy } & \multicolumn{2}{c|}{ Siwi } & \multicolumn{2}{c|}{ Samani } \\
\cline { 5 - 10 } & & & fruits & leaves & fruits & leaves & fruits & leaves \\
\hline Philodromidae & Philodromus sp. & Adult & - & - & - & - & - & +++ \\
Thanatus albini & Adult & + & ++ & + & +++ & + & +++ \\
\hline Salticidae & Theyene imperialis & Adult & + & + & - & + & - & +++ \\
\hline Miturgidae & Cheiracanthium sp. & Adult & - & - & - & - & + & ++ \\
\hline Hersilidae & unknown & Immature & + & - & - & - & + & - \\
\hline Lycosidae & Hogna ferox & Adult & + & + & + & - & + & - \\
\hline
\end{tabular}

$+=$ rare $(1-3)$ individuals $++=$ moderate $(4-9)$ individuals $+++=$ high (more than 9 individuals) 
True spiders inhabiting date palm varieties with special reference to ............

Table (2): Survey of true spiders on Apremy variety fruits in stores at different regions.

\begin{tabular}{|l|c|c|c|c|}
\hline \multicolumn{1}{|c|}{ Region } & Family & species & Stage & Abundance \\
\hline $\begin{array}{l}\text { Giza, Gharbia, Menoufia } \\
\text { and Beheira }\end{array}$ & Lycosidae & Hogna ferox & Adults & + \\
\hline $\begin{array}{l}\text { Menoufia, Beni -Sweief, } \\
\text { Menia and Gharbia }\end{array}$ & Thomisidae & $\begin{array}{c}\text { Thomisus } \\
\text { spinifer }\end{array}$ & All stages & ++ \\
\hline Sharkia and Dimetta & Linyphiidae & Erigone sp. & Adults & ++ \\
\hline Fayoum & Hersilidae & unknown & Immatures & + \\
\hline Cairo and Gharbia & Uloboridae & Uloborus sp. & Immatures & + \\
\hline
\end{tabular}

Also, from the obtained data, it was noticed that the geographical localities were highly affected the occurrence of different species, where Hogna ferox and Thomisius spinifer were found in many regions than other species and this show the importance of geographical regions in spider distribution and abundance. The obtained results were confirmed by those obtained by Sallam et al. (2007) where they found 17 families on date palm in Rashid region of Egypt on all parts of the plants, where the most important collected families were Agelinidae, Theridiidae and Lycosidae.

\section{3- Biological aspects of Thanatus albini spider reared on red palm weevil larvae: \\ 3.1. Feeding behavior:}

The adult and immatures of the spider, T. albini closed slowly to the prey and moved around the prey for a few seconds then caught it between its chelicerae, then embedded its chelicerae in the prey body which was partially injured, and this was repeated several times.

\subsection{Mating:}

The virgin female stayed feeding for an average of $\mathbf{1 2 . 5}$ days before mating, after that female were transported to the male rearing container, where male started to come close to the female in a relative movements for about 2-3 minutes, then climbed on her back for a while, then descended female raised her body laterally, then male move under her, clasped all her appendages beneath her body. The ventral side of male body was facing the female ventral side, and then copulation occurred for 2-3 minutes. During this process, male was without any motion, then moved for 5-10 second several times. After a short time from the first mating, the male repeated the mating process but from the other side of female body. The mating process took about 10 15 minutes.

3.3. Oviposition and eggs incubation:

The gravid females of the predator spider, T. albini which reared on red palm weevil larvae were laid its eggs in sacs, and each one contained 25-30 egg. The mean incubation periods were $18.0 \pm 0.81$ and $17.66 \pm 0.69$ days for female and male, respectively. Eggs were yellowish in color; almost spherical then became darker before hatching. The spiderlings stayed together before getting out from the egg sac. The newly hatched spiderlings did not feed for about 3 hours, and before the end of each spiderling stage individual rested for about 3 hours before the emergence of the following stage. 
3.4. Developmental stages of Thanatus albini reared on red palm weevil larvae:

The obtained results in Table (3) showed that the mean egg incubation period was lasted $\mathbf{1 8 . 0}$ and $\mathbf{1 7 . 6 6}$ days for female and male, respectively, at $25 \pm 2^{\circ} \mathrm{C}$ and $60 \pm 5 \% \mathrm{RH}$. The duration of different spiderlings of female from $1^{\text {st }}$ spiderling to the $7^{\text {th }}$ averaged $25.00,22.60,22.13$, $21.35,20.13,20.33$ and 20.26 day, respectively, while those of male were lasted 22.80 , $20.80,19.46,10.40,19.66,19.13$ and 19.00 days, respectively. The total duration of male life cycle (egg + immatures) was shorter than that of female, averaging 148.73 and 169.87 days, respectively.

3.5. Food consumption of $T$. albini fed on $R$. ferrugineus larvae:
The obtained results in Table (4) revealed that the seven spiderlings stages of the spider $T$. albini female consumed an averages of $79.85,99.57$, $89.50,61.35,48.64,70.92$ and 42.00 larvae of the red palm weevil, $R$. ferrugineus, respectively, while male spiderlings consumed $33.80,66,71,42.00,53.64$, 27.28, 44.92 and 42.00 larvae of the red palm weevil, $R$. ferrugineus, respectively. Thus, during the life cycle of the female, spiderlings consumed $491.83 \pm 46.81$ larvae of $\boldsymbol{R}$. ferrugineus, while along male stage, spiderlings consumed $310.35 \pm$ 47.76 larvae.

From the obtained results, it can be concluded that the tested spider may be considered one of the successful bio control agent that play an important role in controlling this pest.

Table (3): Duration of different stages of the spider, Thanatus albini, Audouin fed on the red palm weevil, Rhynchophorus ferrugineus at $25 \pm 2{ }^{\circ} \mathrm{C}$ and $60 \pm 5 \% \mathrm{RH}$.

\begin{tabular}{|l|c|c|}
\hline \multirow{2}{*}{ Developmental stages } & \multicolumn{2}{|c|}{ Duration (days) } \\
\cline { 2 - 3 } & Female \pm SE & Male \pm SE \\
\hline Egg incubation period & $18.00 \pm 0.81$ & $17.66 \pm 0.69$ \\
$1^{\text {st }}$ spiderling & $25.00 \pm 1.03$ & $22.80 \pm 1.10$ \\
$2^{\text {nd }}$ spiderling & $22.60 \pm 1.08$ & $20.80 \pm 1.20$ \\
$3^{\text {rd }}$ spiderling & $22.13 \pm 1.54$ & $19.46 \pm 0.80$ \\
$4^{\text {th }}$ spiderling & $21.35 \pm 1.02$ & $10.40 \pm 1.01$ \\
$5^{\text {th }}$ spiderling & $20.13 \pm 1.20$ & $19.66 \pm 1.29$ \\
$6^{\text {th }}$ spiderling & $20.33 \pm 1.29$ & $19.13 \pm 1.14$ \\
$7^{\text {th }}$ spiderling & $20.26 \pm 1.18$ & $19.00 \pm .073$ \\
\hline Life cycle & $169.87 \pm 5.29$ & $148.73 \pm 3.37$ \\
\hline
\end{tabular}

Table (4): Food consumption of Thanatus albini, Audouin fed on larvae of the red palm weevil, Rhynchophorus ferrugineus at $25 \pm 2{ }^{\circ} \mathrm{C}$ and $60 \pm 5 \% \mathrm{RH}$.

\begin{tabular}{|l|c|c|}
\hline \multirow{2}{*}{ Spiderling stages } & \multicolumn{2}{|c|}{ Average no of larvae consumed by T.albini stages } \\
\cline { 2 - 3 } & Female \pm SE & Male \pm SE \\
\hline $1^{\text {st }}$ spiderling & $79.85 \pm 6.65$ & $33.80 \pm 9.98$ \\
$2^{\text {nd }}$ spiderling & $99.57 \pm 8.70$ & $66.71 \pm 9.50$ \\
$3^{\text {rd }}$ spiderling & $89.50 \pm 6.78$ & $42.00 \pm 5.55$ \\
$4^{\text {th }}$ spiderling & $61.35 \pm 1.42$ & $53.64 \pm 0.50$ \\
$5^{\text {th }}$ spiderling & $48.64 \pm 6.98$ & $27.28 \pm 5.38$ \\
$6^{\text {th }}$ spiderling & $70.92 \pm 7.85$ & $44.92 \pm 8.40$ \\
$7^{\text {th }}$ spiderling & $42.00 \pm 8.43$ & $42.00 \pm 8.45$ \\
\hline Life cycle & $491.83 \pm 46.81$ & $310.35 \pm 47.76$ \\
\hline
\end{tabular}




\section{REFERENCES}

Ahmad, N. R. and H. M. Heikal (2016). The biological characteristics study of the spider, Theridion spinitarse 0. Pickard-Cambridge, 1876 (Araneae: Theridiidae) in Egypt. Menoufia $\mathbf{J}$. Plant Prot., Vol. 1: 1 - 7.

Agnew, C. W., A. D. Deen and J. W. J. R. Smith (1985). Spider collected from peanuts and non-agriculture habitats in the Texas cross-timbers. The Southwest Tern Nat., 30: 1-12.

Barrin, A. T. and J. A. Litsinger (1995). Riceland and spider of South and Southeast Asia. Rice Res. Institute, Manila, Philippines, 19, 700 pp.

Coddington, J. A. (1986). The genera of the spider family Theridiosomatidae. Smithsonian Contributions of Zoology 422: 1-96.

El-Erksousy, M. H. (2000). Studies on some true spider in Egypt. Ph. D. Thesis, Fac. Agric. Al-Azhar Univ., 130 pp.

El-Erksousy, M. H. (2003). Biology of the spider, Theridion egyptium Fawzy \& El-Erksousy fed on Spodoptera littoralis larvae. Bull. Ent. Soc. Egypt, 80: 229-233.

El-Erksousy, M. H., Gehad M. Mousa and Wafaa O. Gomaa (2002). The spider Theridion egyptiacum sp.n., Fawzy and El-Erksousy as a biological control agent on cotton aphid, Aphis gossypii Glover. The $2^{\text {nd }}$ Conf. Plant Protect. Res. Inst., Cairo, Egypt, 21-24 December, 2002, 26-27.

El-Erksousy, M. H., A. A. Shoeib and Wafaa O. Gomaa (2006). Biology of the spider, Steatoda triangulosa (Walkckenare) fed on larvae of Spodoptera littoralis. The $2^{\text {nd }}$ Conf. on Farm Integrated Pest Management, 1618 Jan. 2006: 256-259.

El-Hennawy, H. K. (1990). Annotated checklist of Egyptian spider species (Arachnidae : Araneae). Serket, 1 (4-5):
1-49.

El-Hennawy, H. K. (2002). Spiders of Sinai (Egypt), A list of species (Arachnidae: Aranedidae). Serket, 7 (1): 29 - 34.

El-Hennawy, H.K. (2006). A list of Egyptian spiders. Serket 10(2): 65-76.

El-Hennawy, H. K. (2010). Notes on Spiders of Africa I. Serket 12(2): 61-75.

El-Sebay, Y. (2000). The Middle East red palm weevil program. Cairo, Egypt, 131 pp.

El-Sebay, Y., M. A. K. El-Lattef and T. M. Makhlouf (2003). Laboratory rearing of red palm weevil, Rhynchophorus ferrugineus (Coleoptera: Curculionidae) on diet. Egypt. J. Agric. Res., 81 (2): 551-554.

Foelix, R.F. (2011). Biology of Spiders. Third Edition. Oxford University.432 pp.

Hussein, A.M. (1999). Seasonal abundance and daily activity pattern of spider fauna in some vegetables crops in Menoufyia Governorate, Egypt. J. Agric. Res. 77(2): 677-689.

Ibrahim, A.A., S.A. Shairra and I.F.S. Elmahdi (2012). Studies on the occurrence of true spiders as natural enemies in many Egyptian fields. The Journal of Basic \& Applied Zoology, 65: 1-3.

Kaston, B. J. (1978). How to know the spiders. W. C. Brown Co., Dubuque. lowa, USA, 722 pp.

Mohamed, M. I. and G. Salam (2003). Biology aspect of the true spider, Thomisus spinifer Cambridge (Thomisidae: Araneae). Egypt, J. Agric. Res., 82: 583-593.

Obuid-Allah, A.H., Amal A. M. and E.H.M. Hussien (2015). Ecology of spiders at Qena governorate, Egypt. The Egyptian Society for Environmental Sci. CATRINA, 10 (1): 75 -82.

Petrunkevitch, A. (1939). Catalogue of American spiders, Vol.1 Trans. Connect. Acad. Sci., 9 (8): 730 - 739. 
Plantnich, N. I. (2004). The world spider catalogue, Version 4.5, Cit net@Copyright 2000, 2001, 2002, 2003, 2004 American Museum of Natural History.

SAS Institute (1988). SASISTAT User's Guide, Ver. 6.03.SAS Institute Inc., Cary, North Carolina, USA.

Sallam, G. M. and E. M. Yassin (2005). Survey of mites and spiders associated with date palm at El-Wahat oasis. Minufia J. Agric. Res.30 (6): 1843 - 1851.

Sallam, G. M., E. M. Yassin and N. A. Abd El-Azeim (2007). The predatory insects, mites and spiders associated with date palm pests in Rashid region,
El-Beheira Governorate, Egypt. Egypt. J. Agric. Res., 85 (1): 37 -51.

Thang, M. H., B. M. Rejesus and K. L. Heong (1990). Comparative toxicity, metabolism and anticholinstrase activity of acephate and propaphos to the brown plant hopper, Nilaparvate lugens (Stal) and the wolf spider Lycosa pseudoannulatus (Boes et Strand)/ Pest Control of the Philippines, Annual Convention, 1 p.

World Spider Catalog. (2015). World Spider Catalog. Natural History Museum Bern, online at http:Il wsc. nmbe.ch, version 16, accessed on \{January 10, 2015\}. 
العناكب الحقيقية المتواجدة على مختلف اصناف النخيل مع الإشارة الى المظاهر البيولوجية للعنكبوت Thanatus albini المربى على سوسة النخيل الحمراء Rhynchophorus ferrugineus

$$
\begin{aligned}
& \text { محمد حسن محمد العرقسوسي(") ، هانى محمد محمد هيكل(؟) ، آمال ابراهيم ابو زيد(') }
\end{aligned}
$$

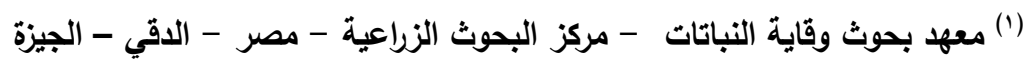

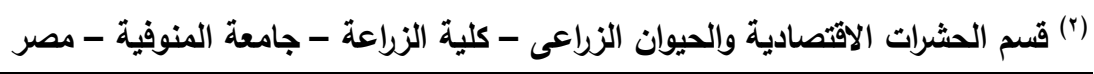

$$
\begin{aligned}
& \text { الملخص العربى الم }
\end{aligned}
$$

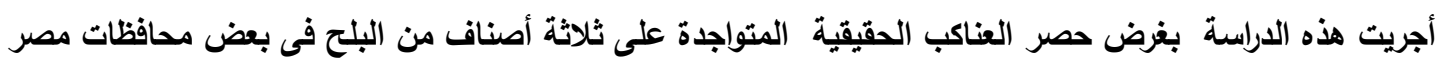

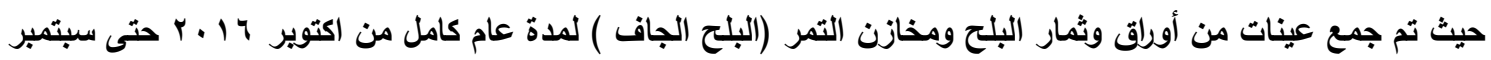

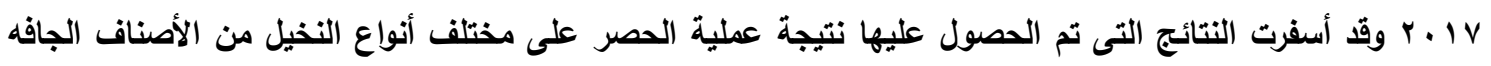

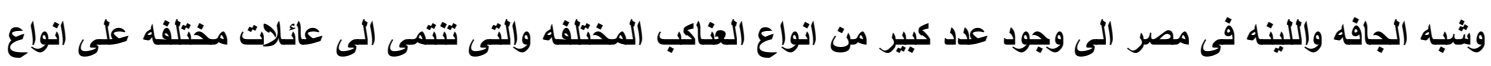

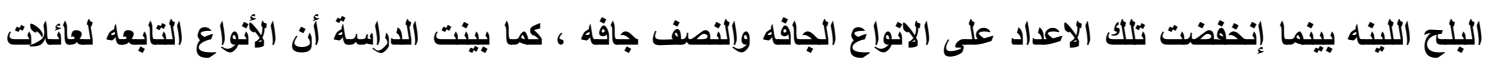

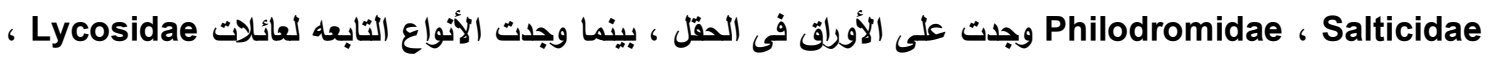
Miturgidae ، Hersilidae

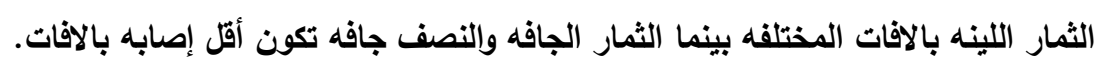

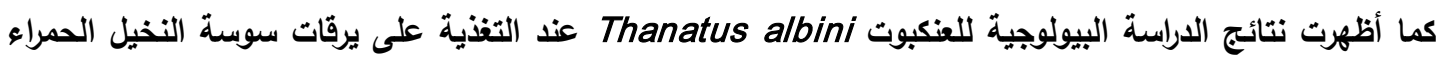
Rhynchophorus ferrugineus

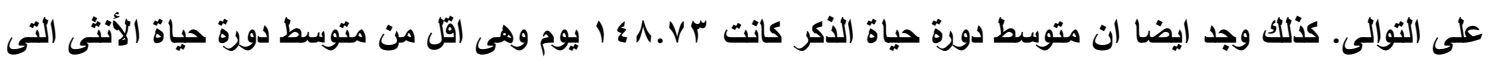

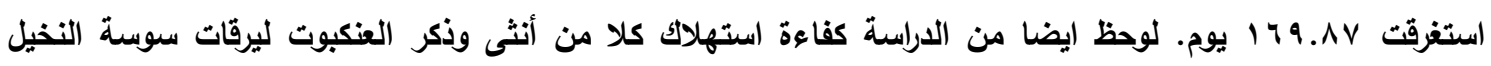

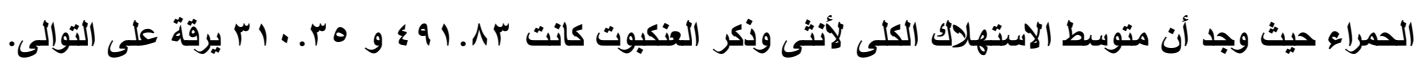

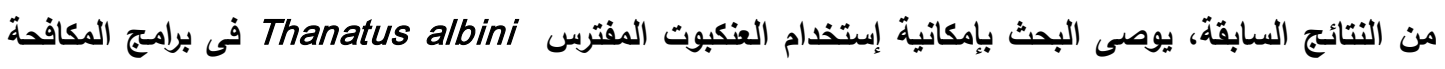

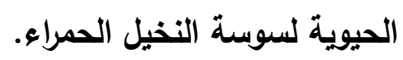

أسماء السادة المحكمين

معهد بحوث وقاية النباتات - الاقى - الجيزة

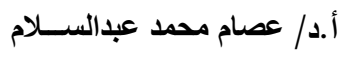

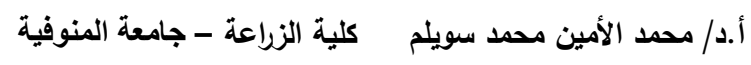


